\title{
ВЫДЕЛЕНИЕ ИЗОЛЯТОВ ВОЗБУДИТЕЛЯ МЫТА ЛОШАДЕЙ В УСЛОВИЯХ КРАЙНЕГО СЕВЕРА
}

\author{
М.П. НЕУСТРОЕВ $1{ }^{\bowtie}$, С.Г. ПЕТРОВА 1 , Е.И. ЭЛЬБЯДОВА 1 , \\ Н.П. ТАРАБУКИНА ${ }^{1}$, В.А. АЛЕКСЕЕВ ${ }^{2}$, А.А. ПОПОВ 1
}

\begin{abstract}
Увеличение поголовья и продуктивности в табунном коневодстве сдерживается рядом факторов, среди которых значительное место занимают инфекционные и инвазионные болезни. Наиболее распространенным и причиняющим ощутимый экономический ущерб заболеванием остается мыт лошадей (возбудитель Streptococcus equi). Заболевание широко распространено в странах азиатского континента, в России и странах СНГ. Для разработки вакцинного препарата против болезни важное значение имеет выделение ее возбудителя. В настоящей работе впервые в условиях Крайнего Севера выделены и идентифицированы три новых изолята возбудителя мыта Streptococcus equi, которые могут быть использованы для диагностики и разработки вакцины против мыта лошадей. Целью работы было выделение, изучение, идентификация по морфологическим, культуральным, биохимическим, молекулярно-генетическим свойствам новых изолятов возбудителя мыта лошадей для диагностики заболевания в условиях Крайнего Севера и разработки вакцины. Биологические пробы были собраны в 2015-2017 годах в хозяйствах Республики Саха (Якутия) (Намский, Хангаласский, Амгинский, Мегино-Кангаласский районы, г. Якутск), а также в Республике Казахстан. Всего исследовали 63 пробы от 6-10-месячных лошадей (Equus ferus caballus) якутской и казахской пород, в том числе 45 смывов носовых истечений (27 от клинически больных мытом жеребят, 18 от здоровых жеребят), 7 проб содержимого вскрывшихся абсцессов подчелюстных лимфатических узлов и 11 паренхиматозных органов павших от мыта жеребят. Перед бактериологическими исследованиями применяли предпосевную обработку. Морфологические и культуральные свойства изолятов изучали при высеве в мясопептонный бульон (МПБ) с $1 \%$ глюкозой и $10 \%$ лошадиной сывороткой, а также на мясопептонный агар (МПА) с $1 \%$ глюкозой и $10 \%$ сывороткой крови или 5 \% дефибринированной кровью лошади. Мазки из гноя, препараты, приготовленные из культур, выращенных в жидкой и на агаризованной среде, фиксировали и окрашивали по Граму. Биохимические свойства культур исследовали при высеве на МПА с 40 \% желчью, 6,5\% солевой МПА, агар с азидом натрия и среды Гисса с глюкозой, лактозой, маннитом, мальтозой, сахарозой, сорбитом и дульцитом. Видовую принадлежность изолятов определяли по биохимическим свойствам культуры с использованием стрипов API 20 Step тест системы API («bioMerieux», Франция). Вирулентную активность стрептококков определяли на белых беспородных мышах, которым подкожно вводили взвесь суточной культуры живых бактериальных клеток стрептококков в объеме $0,2-0,5 \mathrm{~cm}^{3}$ (от $1 \times 10^{3}$ до $1 \times 10^{9}$ КОЕ/гол). ДНК выделяли из жидкой бактериальной культуры. Генетическое типирование изолятов Streptococcus выполняли методом ПЦР со штамм-специфическими праймерами Seel-F 5'-CGGATACGGTGATGTTAAAGA-3' и Seel-R 5'-TTCCTTCCTCAAAGCCAGA-3'. Нуклеотидная последовательность гена 16S pPHK Streptococcus equi была секвенирована для шести изолятов мытного стрептококка, из которых три предлагается использовать для разработки вакцинных препаратов. Полимеразная цепная реакция со специфическими праймерами служит наиболее достоверным и быстрым методом идентификации мытного стрептококка. По результатам генотипирования и изучения культуральных, морфологических и биохимических свойств установлено, что изолят Н-5/1 относится к семейству Streptococcaceae, роду Streptococcus, виду Streptococcus equi ssp. equi и соответствует типовым характеристикам представителей этого вида. Нуклеотидная последовательность фрагмента гена 16S рРНК изолята Н-5/1 после секвенирования депонирована в базе данных NCBI GenBank (MW486609). На основании проведенных исследований штамм Streptococcus equi H-5/1 депонирован во Всероссийской государственной коллекции штаммов микроорганизмов, используемых в ветеринарии и животноводстве ФГБУ ВГНКИ (регистрационный номер ВКШМ-Б-141П, справка о депонировании от 22 мая 2018 года). Получен патент на изобретение № 2703485 «Штамм бактерий Streptococcus equi, используемый для изготовления вакцины против мыта» от 17.10.2019 года. Новые изоляты Streptococcus equi могут быть использованы для разработки диагностических препаратов и вакцины против мыта лошадей. Также от клинически больных мытом жеребят были выделены культуры Enterococcus faecales, Streptococcus piogenes, токсигенные и плесневые грибы родов Aspergillus и Mucor, что необходимо учитывать при диагностике и профилактике мыта и других респираторных болезней молодняка лошадей.
\end{abstract}

Ключевые слова: мыт лошадей, стрептококк, Streptococcus equi, биохимиеские признаки, генотипирование, якутские породы, Сибирь, Крайний Север, бактериальные инфекции.

Коневодство - одна из основных отраслей животноводства во мно- 
гих странах. К факторам, сдерживающим ее развитие, можно отнести инфекционные болезни лошадей, среди которых наиболее распространен мыт (возбудитель Streptococcus equi) $(1,2)$. Существует мнение, что возбудитель мыта значительно не менялся в течение 700 лет, хотя не отрицаются зональные особенности штаммов (3). Болезнь регистрируют в России в Новосибирской области, Красноярском и Алтайском краях, республиках Хакасия, Саха (Якутия) и Алтай, в Иркутской области, а также в Казахстане, Кыргызстане, Монголии (4-6).

В Республике Саха (Якутия), где развито табунное коневодство, заболеваемость молодняка лошадей мытом составляет 57,8-62,7 \% от общего поголовья, летальность в зависимости от развития эпизоотического процесса достигает 4,0-22,0 \% (6). Заболеваемость мытом в Республике Казахстан составляет 30,1-46,7 \%, летальность - 16,0-28,3 \% (7). В 2017-2020 годах случаи заболевания регистрировали у 42-59 \% молодняка лошадей якутских пород (собственные неопубликованные данные).

Для разработки эффективных методов диагностики, профилактики и терапии мыта необходимо изучение возбудителя болезни в разных регионах (8). Во всех странах, где встречается мыт лошадей, включая Казахстан (7), Кыргызстан (9), Нидерланды (10), Арабскую Республику Египет (11), Россию (6, 12), Корею (13), Бразилию (14), выделение и идентификацию мытного стрептококка проводят на основе морфологических, культуральных и биохимических свойств. В последние годы с развитием молекулярно-генетических исследований появились сообщения об идентификации возбудителя с использованием полимеразной цепной реакции (ПЦР) на основе видоспецифичных генов, потенциально участвующих в формировании вирулентного фенотипа Streptococcus equi (2, 15-18). Полученные штаммы применяются для диагностики и изготовления вакцин в США, Казахстане и Нидерландах $(7,8,10)$.

В литературе имеются сообщения о том, что возбудитель мыта лошадей может вызывать артриты у козлят (19) и аборты у кобыл (6). Мытный стрептококк выделяют и у клинически здоровых лошадей, поскольку они становятся его переносчиками $(6,13,14)$. Ранее штамм Streptococcus equi Н-34 был депонирован нами во Всероссийском государственном центре качества и стандартизации лекарственных средств для животных и кормов (ВГНКИ, г. Москва) и предложен для производства вакцин против мыта и диагностической стрептококковой сыворотки серогруппы С (6). В настоящее время этот штамм снят с депонирования в связи с утратой специфических антигенных свойств, то есть в Российской Федерации отсутствует вакцина против мыта лошадей. В других странах изготовлены различные вакцины, которые не имеют регистрации в России $(7,8,10)$.

В настоящей работе в условиях Крайнего Севера выделены и идентифицированы три новых изолята возбудителя мыта Streptococcus equi, которые могут быть использованы для диагностики и разработки вакцины против мыта лошадей.

Цель работы - выделение, изучение, идентификация по морфологическим, культуральным, биохимическим и молекулярно-генетическим свойствам новых изолятов возбудителя мыта лошадей

Методика. Биологические пробы были собраны в 2015-2017 годах в хозяйствах Намского, Хангаласского, Амгинского, Мегино-Кангаласского районов и г. Якутске Республики Саха (Якутия), а также а Республике Казахстан. Всего исследовали 63 пробы, полученные от лошадей (Equus ferus caballus) якутской и казахской пород 6-10-месячного возраста, в том числе 
45 смывов носовых истечений (27 от клинически больных мытом жеребят, 18 от здоровых жеребят), 7 проб содержимого вскрывшихся абсцессов подчелюстных лимфатических узлов и 11 паренхиматозных органов павших от мыта жеребят.

Перед бактериологическими исследованиями применяли предпосевную обработку. Смывы с зонд-тампонами, кусочки органов и лимфоузлов погружали на 5 мин в стерильный физиологический раствор, затем обрабатывали $70^{\circ}$ спиртом с последующим промыванием 2-3 раза в физиологическом растворе.

Морфологические и культуральные свойства изолятов изучали при высеве в мясопептонный бульон (МПБ) с 1 \% глюкозой и $10 \%$ лошадиной сывороткой, а также на мясопептонный агар (МПА) с $1 \%$ глюкозой и $10 \%$ сывороткой крови или $5 \%$ дефибринированной кровью лошади. Мазки из гноя и препараты культур фиксировали и окрашивали по Граму. Биохимические свойства изолятов исследовали при высеве на МПА с 40 \% желчью, на 6,5 \% солевой МПА, агар с азидом натрия и среды Гисса с глюкозой, лактозой, маннитом, мальтозой, сахарозой, сорбитом и дульцитом. Культуры инкубировали в термостате ТС-1/80 СПУ (ОАО «Смоленское СКТБ СПУ», Россия) при $37^{\circ} \mathrm{C}$ в течение 18-48 ч.

Таксономическую принадлежность выделенных культур устанавливали согласно «Краткому определителю бактерий Берджи» (20), также следовали методическим указаниям по лабораторной диагностике мыта, стафилококкозов и стрептококкозов $(21,22)$. Для видовой идентификации изолятов по биохимическим свойствам использовали стрипы API 20 Step тест системы API («bioMerieux», Франция).

Образцы изолятов стептококков из полужидкого агара пересевали в триптон-соевый бульон и культивировали при $37^{\circ} \mathrm{C}$ в течение 48 ч. Затем пересевали на чашки с кровяным агаром и плотную питательную среду (колумбийский агар) с теллуратом калия. Чашки помещали в термостат при $37{ }^{\circ} \mathrm{C}$ на 24 ч. Определяли культуральные и морфологические свойства, тип гемолиза, наличие каталазной активности, готовили мазки. Агаровые культуры пересевали на чашки с колумбийским агаром и культивировали 24 ч при $37^{\circ} \mathrm{C}$. Из культур готовили суспензию в физиологическом

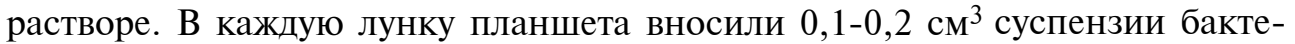
рий. Добавляли реактивы и стерильное вазелиновое масло. Инкубировали 5-24 ч при $38{ }^{\circ} \mathrm{C}$. Результаты учитывали с помощью таблицы «Интерпретация реакций» тест-системы и обрабатывали в программе Microsoft Excel.

При оценке вирулентности стрептококков использовали белых беспородных мышей $(n=70)$ обоего пола 5-8-недельного возраста массой 18-20 г. Мышам подкожно вводили взвесь суточной культуры живых бактериальных клеток стрептококков в объеме $0,2-0,5 \mathrm{~cm}^{3}$ (от $1 \times 10^{3}$ до $1 \times 10^{9}$ KOE/гол.). Вирулентную активность изолятов LD50 определяли методом Кербера в модификации И.П. Ашмарина и А.А. Воробьева (23).

Для выделения ДНК (24) 1,5 мл жидкой бактериальной культуры центрифугировали на многофункциональной центрифуге 5804R («Eppendorf», Германия) до формирования плотного осадка, осадок растворяли в 567 мкл ТЕ буфера, добавляли 30 мкл 10 \% SDS и 3 мкл протеиназы К (20 мг/мл) до конечной концентрации 100 мкг/мл. После инкубации при $37{ }^{\circ} \mathrm{C}$ в течение 1 ч раствор становился вязким, что указывало на разрушение клеточной стенки. Далее к нему добавляли 100 мкл $5 \mathrm{M} \mathrm{NaCl}$ и тщательно перемешивали, после чего вносили 80 мкл раствора СТАВ/ $\mathrm{NaCl}$ и инкубировали 10 мин при $65^{\circ} \mathrm{C}$. Затем к раствору приливали примерно 
равный объем смеси хлороформа и изоамилового спирта в пропорциях 24:1, тщательно перемешивали и центрифугировали в течение 5 мин. Супернатант переносили в чистую пробирку, добавляли равное количество смеси фенола, хлороформа и изоамилового спирта (25:24:1), перемешивали и центрифугировали в течение 5 мин.

Для осаждения ДНК супернатант переносили в чистую пробирку и добавляли изопропанол в объеме, равном примерно 0,6 от количества исходного супернатанта. Осадок ДНК промывали 70 \% этанолом, высушивали и растворяли в 30 мкл ТЕ буфера. Оценивали качество и концентрацию полученного препарата ДНК (спектрофотометр NanoPhotometer ${ }^{\mathrm{TM}}$ P330, «Implen», Германия).

При генотипировании изолятов Streptococcus проводили ПЦР, используя штамм-специфичные праймеры Seel-F 5'-CGGATACGGTGATGTTAAAGA-3' и Seel-R 5'-TTCCTTCCTCAAAGCCAGA-3' (17, 18) (амплификатор CFX-96, «Bio-Rad», США) и набор qPCRmix-HS LowROX («Evrogen», Россия). Режим постановки ПЦР и состав реакционной среды выбирали в соответствии с инструкциями производителя набора. Каждая реакционная смесь объемом 25 мкл состояла из 5 мкл qPCRmix-HS LowROX (мастермикс), 2 мкл каждого из праймеров (1,0 мкл) и 18 мкл очищенной от нуклеаз воды. Условия ПЦР были следующими: 5 мин при $95{ }^{\circ} \mathrm{C} ; 35$ циклов 30 с при $95^{\circ} \mathrm{C}, 30$ с при $55^{\circ} \mathrm{C}, 30$ с при $72{ }^{\circ} \mathrm{C}$. Продукты ПЦР визуализировали при помощи электрофореза в 1,5\% агарозном геле, содержавшем бромистый этидий в качестве интеркалирующего красителя; напряженность электрического поля $6 \mathrm{~B} / \mathrm{cм}$. Чувствительность и достоверность метода ПЦР для идентификации мытного стрептококка была подтверждена исследованиями в Отделении качества и стандартизации пробиотических препаратов ФГБУ Всероссийский государственный центр качества и стандартизации лекарственных средств для животных и кормов (г. Москва).

Секвенирование гена $16 \mathrm{~S}$ рРНК проводилось в ЦКП «Геномика» (ИХБФМ СО РАН, г. Новосибирск). Ампликон размером около 1500 п.н. получали с использованием специфических 16S праймеров (27F: 5'-AGAGTTTGATCMTGGCTCAG-3' и 1492R: 5'-GGTTACCTTGTTACGACTT-3') для каждого изолята в препаративном количестве и очищали с помощью сорбции на магнитных частицах (Agencourt AMPure XP, «Beckman Coulter, Inc.», США). Секвенирование по Сэнгеру выполняли на АВI 3130xl Genetic Analyser («Applied Biosystems», США) по стандартным протоколам производителя. Нуклеотидные последовательности анализировали с помощью BLAST (https://blast.ncbi.nlm.nih.gov/Blast.cgi) для выявления гомологии с нуклеотидными последовательностями, депонированными в базе данных GenBank (https://www.ncbi.nlm.nih.gov/genbank/).

Результаты. Для первичных бактериологических исследований биологических материалов, полученных от клинически больных мытом лошадей (рис. 1), в 2015-2016 годах отобрали 40 культур, схожих с мытным стрептококком по культуральным, ферментативным и гемолитическим свойствам. В 11 пробах обнаружили контаминированность токсигенными и плесневыми грибами родов Aspergillus и Mucor.

Предпосевная обработка оказалась весьма эффективной для подавления роста сопутствующей микрофлоры, что приводило к облегчению и ускорению срока выделения чистой культуры. Прижизненная диагностика мыта лошадей, особенно в условиях Крайнего Севера, остается сложной задачей. Нами установлено, что некачественный и скудный рацион способствует поражению грибами респираторного тракта животных, которое 


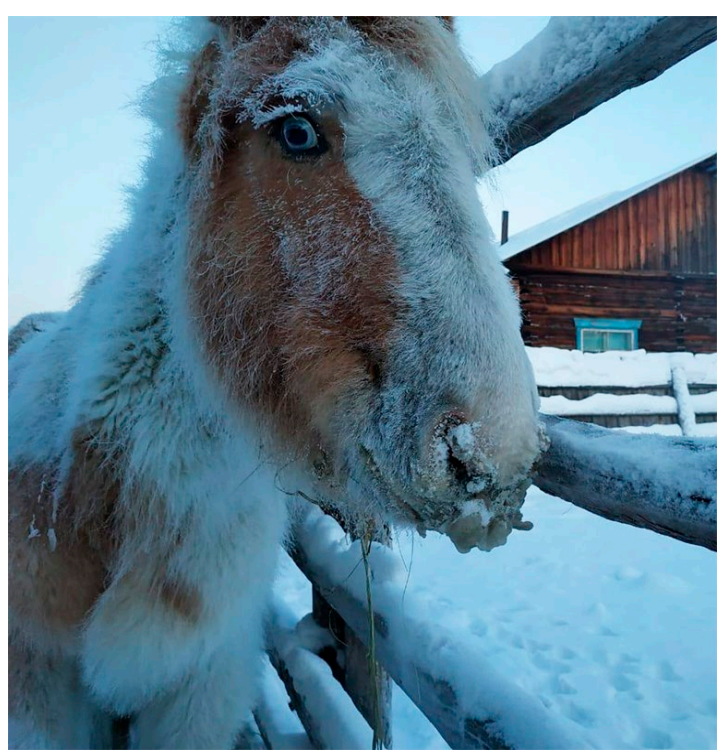

Рис. 1. Слизисто-гнойные носовые выделения у клинически больного мытом жеребенка (Equus ferus caballus) якутской породы (Хангаласский р-н, с. Немюгюнцы, 2017 год).

В дальнейшем 7 изолятов дали рост на МПА с 1 \% глюкозой и $40 \%$ желчью крупного рогатого скота и на МПА с 6,5 \% хлоридом натрия, а также ферментировали глюкозу, лактозу, мальтозу, маннит, сорбит и дульцит с образованием кислоты без газа. Эти изоляты характеризовались придонным ростом в виде плотного белого осадка на жидких питательных средах. На плотных средах они росли в виде слизистых колоний белого цвета. На среде с теллуратом калия были получены колонии черного цвета. Каталазная активность отсутствовала. В бульонной культуре световая микроскопия выявила короткие цепочки кокков, в окрашенных по Граму препаратах культур, выращенных на плотной питательной среде, - кокки в виде «виноградных гроздьев».

Результаты видовой идентификации стрептококков выделенных от больного мытом молодняка лошадей (Equus ferus caballus) якутской и казахской пород (Республика Саха - Якутия, Республика Казахстан, 2015-2017 годы)

\begin{tabular}{l|c|c}
\hline \multirow{2}{*}{ Изолят } & \multicolumn{2}{|c}{ Идентификация } \\
\cline { 2 - 3 } & генотипирование с использованием ПЦР & по биохимическим свойствам \\
\hline П1 & Streptococcus equi & - \\
$\mathrm{H}-1$ каз & Streptococcus equi & Streptococcus equi \\
$\mathrm{H}-5 / 1$ & Streptococcus equi & Streptococcus equi \\
$\mathrm{H}-12-3$ & Streptococcus equi & Streptococcus equi \\
$7-3$ & Streptococcus equi & - \\
$1-3$ & Streptococcus equi & - \\
$\mathrm{H}-34$ & - & Enterococcus faecalis \\
Хатас-3 & - & Streptococcus pyogenes \\
ЧГ & - & Enterococcus faecalis \\
4 г & - & Enterococcus faecalis \\
МК $1 / 1$ & - & Enterococcus faecalis \\
ЮГ & - & Enterococcus faecalis \\
SМ & - & Enterococcus faecalis \\
М & - & Enterococcus faecalis \\
П р и м е ч а н и е. Прочерки означают, что изоляты не были исследованы соответствующим методом. \\
\hline
\end{tabular}

На основании биохимических и культурально-морфологических 
свойств изоляты 4г, MK 1/1, ЮГ, SM, H-34 и М были отнесены к виду Enterococcus faecalis, а изолят Хатас-3 - к виду Streptococcus piogenes (табл.). На этом этапе исследований нам не удалось выделить возбудителя мыта Streptococcus equi из-за высокой контаминации образцов токсигенными и плесневыми грибами, а также ассоциацией бактерий рода Streptococcus. Исходя из полученных результатов, следует отметить роль Enterococcus faecales и Streptococcus piogenes в развитии инфекционного процесса при заболевании органов дыхания.

В октябре-ноябре 2017 года от больных мытом жеребят были дополнительно получены новые изоляты стрептококков, которые в жидкой питательной среде характеризовались пристеночным ростом с образованием белого хлопьевидного осадка (рис. 2, А), а на плотной питательной среде формировали росинчатые полупрозрачные мелкие колонии (см. рис. 2 , Б). На кровяном агаре давали $\beta$-гемолиз (см. рис. 2 , В). Изоляты не росли на средах с добавлением желчи и хлорида натрия, ферментировали глюкозу и лактозу с образованием кислоты без газа, не сбраживали маннит, сорбит, дульцит. При микроскопировании препаратов, окрашенных по Граму, в суточной бульонной культуре выявили длинные извитые цепочки из грамположительных кокков, в колониях, выросших на агаризованной среде, - короткие цепочки или парные и одиночные кокки. Морфологические и культурально-биохимические свойства этих изолятов были характерны для мытного стрептококка.

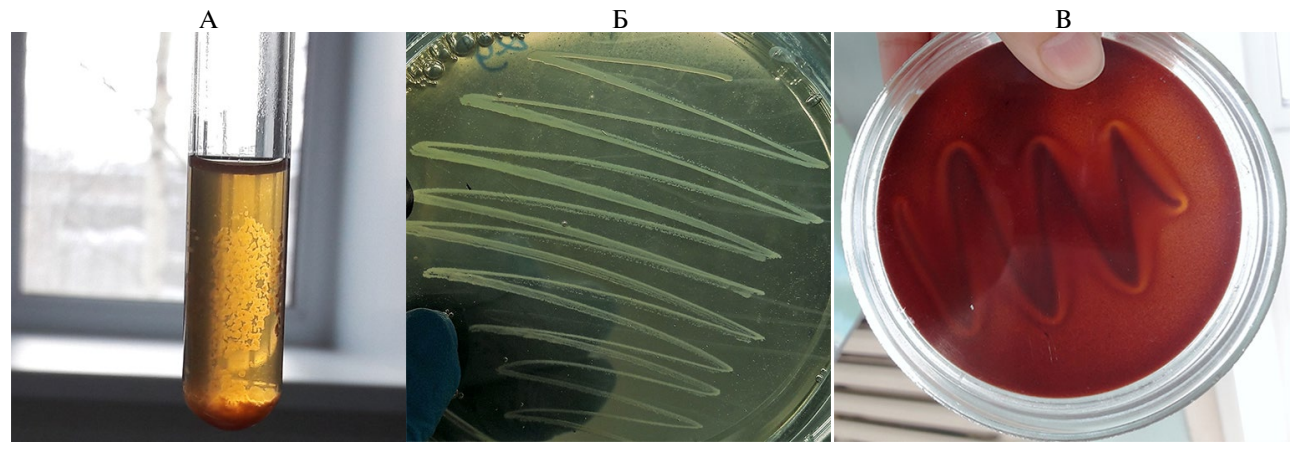

Рис. 2. Рост Streptococcus equi, выделенного из носовой полости у больного мытом молодняка лошади (Equus ferus caballus) якутской породы, в мясопептонном бульоне (А), на мясопептонном aгаре (Б), на кровяном агаре ( $\beta$-гемолиз) (В) (Республика Саха - Якутия, Республика Казахстан, 2017 год).

При исследовании 40 изолятов нуклеотидную последовательность гена 16S pPHK Streptococcus equi обнаружили у шести изолятов (П1, Н-1 каз, Н-5/1, Н-12-3, 1-3, 7-3), полученных от клинически больных мытом жеребят. Для разработки вакцинного препарата отобрали три - Н-1 каз, Н-5/1 и Н-12-3. Штамм Н-34, депонированный ранее как Streptococcus equi (Bceроссийская коллекция клеточных культур, штаммов вирусов, микробов и микропатогенов, ВГНКИ, г. Москва; в настоящее время снят с депонирования), в результате частых пересевов при длительном хранении более не соответствовал нормативам тест-системы и заявленным характеристикам (см. табл.). Молекулярно-генетическое типирование подтвердило, что анализируемая нуклеотидная последовательность штаммов Н-5/1, Н-12-3, Н-1 каз на $100 \%$ идентична нуклеотидной последовательности фрагмента гена $16 \mathrm{~S}$ рРНК Streptococcus equi. Из них штамм Streptococcus equi Н-5/1 как самый перспективный прошел комиссионные испытания в Отделении ка- 
чества и стандартизации пробиотических препаратов ФГБУ ВГНКИ (отдел Всероссийская коллекция штаммов микроорганизмов).

Штамм Streptococcus equi H-5/1 продуцировал ферменты $\beta$-глюкозидазу, $\beta$-глюкуронидазу и лейцинариламидазу, ферментировал эскулин, крахмал и гликоген с образованием кислоты без газа, не сбраживал аргинин, рибозу, арабинозу, маннит, сорбит, лактозу, трегалозу, инулин и раффинозу, не образовывал ацетоин и не гидролизовал гиппурат.

LD50 штамма Streptococcus equi H-5/1 для белых мышей составляла $1 \times 10^{2} \mathrm{KOE/гол.} \mathrm{при} \mathrm{парентеральном} \mathrm{введении.}$

Анализ секвенограмм гена $16 \mathrm{~S}$ рРНК для изолята Н-5/1 позволил получить следующую нуклеотидную последовательность:

TGCAAGTGGAACGCACAGATGATACGTAGCTTGCTACAATTATCTGTGAGTCGCGAACG GGTGAGTAACGCGTAGGTAACCTAGCTTATAGCGGGGGATAACTATTGGAAACGATAGC TAATACCGCATAAAAGTGGTTGACCCATGTTAACCATTTAAAAGGAGCAACAGCTCCACTA TGAGATGGACCTGCGTTGTATTAGCTAGTTGGTAGGGTAAAGGCCTACCAAGGCGACGA TACATAGCCGACCTGAGAGGGTGAACGGCCACACTGGGACTGAGACACGGCCCAGACT CCTACGGGAGGCAGCAGTAGGGAATCTTCGGCAATGGGGGGAACCCTGACCGAACAAC GCCGCGTGAGTGAAGAAGGTTTTCGGATCGTAAAGCTCTGTTGTTAGAGAAGAACAGTG ATGGGAGTGGAAAGTCCATCATGTGACGGTAACTAACCAGAAAGGGACGGCTAACTACG TGCCAGCAGCCGCGGTAATACGTAGGTCCCGAGCGTTGTCCGGATTTATTGGGCGTAAA GCGAGCGCAGGCGGTTTGATAAGTCTGAAGTTAAAGGCAGTGGCTTAACCATTGTATGC TTTGGAAACTGTTAAACTTGAGTGCAGAAGGGGAGAGTGGAATTCCATGTGTAGCGGTG AAATGCGTAGATATATGGAGGAACACCGGTGGCGAAAGCGGCTCTCTGGTCTGTAACTG ACGCTGAGGCTCGAAAGCGTGGGGAGCAAACAGGATTAGATACCCTGGTAGTCCACGC CGTAAACGCTGAGTGCTAGGTGTTAGGCCCTTTCCGGGGCTTAGTGCCGGAGCTAACG CATTAAGCACTCCGCCTGGGGAGTACGACCGCAAGGTTGAAACTCAAAGGAATTGACGG GGGCCCGCACAAGCGGTGGAGCATGTGGTTTAATTCGAAGCAACGCGAAGAACCTTACC AGGTCTTGACATCCCGATGCTATTCTTAGAGATAAGAAGTTACTTCGGTACATTGGAGAC AGGTGGTGCATGGTTGTCGTCAGCTCGTGTCGTGAGATGTTGGGTTAAGTCCCGCAAC GAGCGCAACCCTTATTGTTAGTTGCCATCATTAAGTTGGGCACTCTAGCGAGACTGCCG GTAATAAACCGGAGGAAGGTGGGGATGACGTCAAATCATCATGCCCCTTATGACCTGGG CTACACACGTGCTACAATGGTTGGTACAACGAGTCGCAAGCCGGTGACGGCAAGCTAAT CTCTGAAAGCCAATCTCAGTTCGGATTGTAGGCTGCAACTCGCCTACATGAAGTCGGAAT CGCTAGTAATCGCGGATCAGCACGCCGCGGTGAATACGTTCCCGGGCCTTGTACACACC GCCCGTCACACCACGAGAGTTTGTAACACCCGAAGTCGGTGAGGTAACCGTTAAGGAGC CAGCCGC

Анализ с помощью BLAST показал, что эта последовательность соответствует генам $16 \mathrm{~S}$ pPHK Streptococcus equi subsp. equi двух штаммов NCTC9682 (MW486609) и АTCC 39506 (MW486609).

Таким образом, по культуральным, морфологическим и биохимическим свойствам, а также по генетическим маркерам изолят Н-5/1 идентифицирован как Streptococcus equi ssp. еqui (семейство Streptococcaceae, род Streptococcus) и соответствует типовым характеристикам представителей этого вида. Нуклеотидная последовательность фрагмента гена $16 \mathrm{~S}$ рРНК изолята H-5/1 после секвенирования депонирована в базе данных NCBI GenBank (MW486609). На основании проведенных исследований штамм Streptococcus equi H-5/1 депонирован во Всероссийской государственной коллекции штаммов микроорганизмов, используемых в ветеринарии и животноводстве ФГБУ ВГНКИ (регистрационный номер ВКШМ-Б-141П, справка о депонировании от 22 мая 2018 года); научная новизна подтверждена патентом на изобретение № 2703485 «Штамм бактерий Streptococcus equi, используемый для изготовления вакцины против мыта» от 17.10.2019 года.

Штамм Streptococcus equi H-5/1 в настоящее время применяется в качестве производственного при изготовлении иммунобиологических препаратов для профилактики мыта лошадей в Российской Федерации. Штамм Streptococcus equi Н-1 каз, выделенный от больной лошади из Республики Казахстан, может быть использован для разработки вакцины, ко- 
торая будет применяться в табунном коневодстве Казахстана. Необходимость выделения штаммов мытного стрептококка в определенных регионах и странах для разработки вакцинных препаратов отмечается многими исследователями $(1,2,8)$.

Выделение из носовой полости токсигенных и плесневых грибов при заболеваниях органов дыхания у молодняка лошадей можно объяснить значительным распространением микроскопических грибов родов Aspergillus u Mucor в растительности тебеневочных пастбищ Якутии, в особенности в дождливые годы $(25,26)$.

Наши результаты согласуются с данными, полученными J. Dauvillier с соавт. (27), которые отмечали присутствие в дыхательных путях лошадей различных грибов и указали на необходимость изучения их роли в этиологии болезней органов дыхания у лошадей и человека. Настораживает факт выделения Streptococcus zooepidemicus, вызывающего тяжелые болезни у людей, из носовой полости у здоровых и больных лошадей (28), хотя мы эти микроорганизмы не обнаружили. При диагностике и профилактике мыта следует учитывать возможность заболевания лошадей ринопневмонией и гриппом. Немаловажно изучение взаимосвязи между бактериальными, вирусными и грибными инфекциями $(6,29,30)$, что может стать направлением будущих исследований.

По нашим данным, при микотоксикозах может быть успешно использован препарат (пробиотик) Сахабактисубтил (Якутский НИИ сельского хозяйства, Россия) (25). При разработке способов профилактики мыта лошадей необходимо предусмотреть использование средств против действия токсигенных грибов и иммуномодуляторы для повышения иммунологической реактивности.

Полученные нами результаты подтверждают, что выделение мытного стрептококка от больных животных и носителей возбудителя стандартными методами культивирования (как и разработка вакцины) затруднено из-за недостаточной чувствительности и трудоемкости (31), особенно в экстремальных условиях табунного содержания. Наиболее чувствительный, специфический и быстрый метод диагностики мыта и идентификации мытного стрептококка - ПЦР-анализ $(15,16,31)$.

Итак, мы выделили и идентифицировали на основе культуральных, ферментативных, гемолитических свойств и генотипирования новые изоляты возбудителя мыта лошадей Streptococcus equi, которые могут применяться как при диагностике этой патологии, так и для разработки вакцин против мыта. Во Всероссийской государственной коллекции штаммов микроорганизмов, используемых в ветеринарии и животноводстве (ФГБУ ВГНКИ), депонирован новый штамм Streptococcus equi H-5/1 (регистрационный номер ВКШМ-Б-141П). Получен патент на изобретение № 2703485 «Штамм бактерий Streptococcus equi, используемый для изготовления вакцины против мыта» от 17.10.2019 года. От клинически больных мытом жеребят выделены культуры Enterococcus faecales, Streptococcus piogenes, токсигенные и плесневые грибы родов Aspergillus и Mucor. Присутствие этих микроорганизмов как возможной патофлоры необходимо учитывать при диагностике и профилактике мыта и других респираторных болезней молодняка лошадей.

ІФГБУН ФИЦ ЯНЦ СО РАН Якутский НИИ

сельского хозяйства им. М.Г. Сафронова,

677001 Россия, Республика Саха (Якутия), г. Якутск,

ул. Бестужева-Марлинского, 23, корпус 1 ,

e-mail: mneyc@mail.ru $₫$, sargy1970p@mail.ru, elbyadova@bk.ru,
Поступила в редакцию 12 февраля 2021 года 


\title{
IDENTIFICATION OF NEW ISOLATES OF THE HORSE STRANGLES CAUSATIVE AGENT IN NORTHERN SIBERIA
}

\author{
M.P. Neustroev ${ }^{\boxplus}$, S.G. Petrova ${ }^{1}$, E.I. Elbyadoval ${ }^{1}$ N.P. Tarabukina ${ }^{1}$, \\ V.A. Alekseev², A.A. Popov ${ }^{1}$
}

\begin{abstract}
${ }^{1}$ Safronov Yakut Research Institute of Agriculture, FRC Yakut Research Center SB RAS, 23/1, ul. BestuzhevaMarlinskogo, Yakutsk, Republic of Sakha (Yakutia), 677001 Russia, e-mail mneyc@mail.ru ( $₫$ corresponding author), sargy1970p@mail.ru, elbyadova@bk.ru, hotubact@mail.ru, andrian.popov.94@bk.ru;

${ }^{2}$ GAU Technopark Yakutia, 1, ul. Truda, Yakutsk, Republic of Sakha (Yakutia), 677001 Russia, e-mail info.excellbio@gmail.com
\end{abstract}

ORCID:

Neustroev M.P. orcid.org/0000-0003-0672-4109

Petrova S.G. orcid.org/0000-0002-9544-9235

Elbyadova E.I. orcid.org/0000-0001-7018-7411

The authors declare no conflict of interests

Received February 12, 2021

Tarabukina N.P. orcid.org/0000-0002-5493-8809

Alekseev V.A. orcid.org/0000-0001-6751-6210

Popov A.A. orcid.org/0000-0002-6599-8401

doi: 10.15389/agrobiology.2021.4.707eng

\section{Abstract}

Infectious and invasive diseases cause significant damage to the economy and decrease the productivity of horse herd farming. Equine strangles (Streptococcus equi) is the most economically damaging. Specific prevention of the disease widespread in Asia, Russia and CIS poses a serious problem. In this work, for the first time in the Far North, we isolated and identified three new Streptococcus equi strains prospective for the diagnostics and development of strangles vaccines. The study aimed to culture, identify morphologically, culturally, biochemically, and genotypically new isolates of the equine strangles causative agent for the development of vaccines. A survey of 6-10-month old Yakut and Kazakh foals (Equus ferus caballus) was performed in the Republic of Sakha (Yakutia) regions (the farms in Namskiy, Khangalasskiy, Amginskiy, Megino-Kangalarskiy districts and in Yakutsk) and in Kazakhstan in 2015-2017. In total, 63 collected biospecimens included 45 nasal discharges (27 from diseased and 18 from healthy foals), 7 submandibular lymph node abscesses, and 11 parenchymal organs. The infectious agents were isolated and identified by $16 \mathrm{~S}$ rDNA genotyping using PCR and based on biochemical traits. Morphological and cultural properties were studied using meat peptone broth (MPB) added with $1 \%$ glucose and $10 \%$ horse blood serum and on meat peptone agar (MPA) with $1 \%$ glucose and $10 \%$ horse blood serum or $5 \%$ defibrinated horse blood. Pus swabs and preparations of liquid and agar cultures stained by the Gram procedure were investigated with a light microscope. Biochemical properties were studied by plating on MPA with $40 \%$ bile, $6.5 \%$ saline MPA, agar with sodium azide, and Giss's medium with glucose, lactose, mannitol, maltose, sucrose, sorbitol, and dulcite. The isolates were biochemically assigned to species using API 20 Step strips (an API test system, bioMerieux, France). The virulence of the isolates (LD50) was assessed on white mice challenged subcutaneously with $0.2-0.5 \mathrm{~cm}^{3}$ of 1 -day suspensions $\left(1 \times 10^{3}\right.$ to $1 \times 10^{9}$ CFU per mouse). Genotyping was performed with specific primers Seel-F 5'-CGGATACGGTGATGTTAAAGA-3' and Seel-R 5'-TTCCTTCCTCAAAGCCAGA-3'. The Streptococcus equi 16S rRNA gene was sequenced for six isolates of strangles streptococcus, of which three we suggest for the development of strangles vaccines. Polymerase chain reaction with specific primers serves as the most reliable and fastest method for identifying strangles streptococcus. Based on genotyping data and the cultural, morphological and biochemical properties, the Streptococcus equi $\mathrm{H}-5 / 1$ isolate belongs to the Streptococcaceae family, Streptococcus genus, Streptococcus equi ssp. equi and corresponds to the typical characteristics of the species. The nucleotide sequence of the 16S rRNA gene fragment of the isolate H-5/1 after sequencing was deposited in the NCBI GenBank database (MW486609). The Streptococcus equi H-5/1 strain was deposited in the All-Russian State Collection of Microorganism Strains Used in Veterinary Medicine and Animal Husbandry (VGNKI, registration number VKSHM-B-141P, certificate of deposit dated May 22, 2018), and patent for invention No. 2703485 ("A strain of bacteria Streptococcus equi used for the production a vaccine against strangles") dated $10 / 17 / 2019$ was received. The new Streptococcus equi strains we described here hold promise in the developing strangles vaccines. Note, Enterococcus faecales, Streptococcus piogenes, toxigenic and mold fungi Aspergillus and Mucor genera were also isolated from foals with clinical sings of equine strangles. Our findings attract attention to these microorganisms possibly involved in the development of equine strangles in young horses, which should be accounted in diagnostics of this pathology. 
Keywords: equine strangles, streptococcus, Streptococcus equi, biochemical traits, genotyping, Yakut horses, Kazakh horses, Siberia, the Far North, bacterial infections.

\section{RE F E R E N C ES}

1. Timoney J.F. The pathogenic equine streptococci. Vet. Res., 2004, 35(4): 397-409 (doi: 10.1051/vetres:2004025).

2. Sweeney C.R., Timoney J.F., Newton J.R., Hines M.T. Streptococcus equi infections in horses: guidelines for treatment, control and prevention of strangles. Journal of Veterinary Internal Medicine, 2005, 19(1): 123-134 (doi: 10.1111/j.1939-1676.2005.tb02671.x).

3. Harris S.R., Robinson C., Steward K.F., Webb K.S., Paillot R., Parkhill J., Holden M.T.G., Waller A.S. Genome specialization and decay of the strangles pathogen, Streptococcus equi, is driven by persistent infection. Genome Research, 2015, 25(9): 1360-1371 (doi: 10.1101/gr.189803.115).

4. Gustokashin K.A. Vestnik Altaiskogo gosudarstvennogo agrarnogo universiteta, 2013, 11(109): 7980 (in Russ.).

5. Bayanzhargal B., Badmaeva O.B., Rinchinova O.N., Tsydypov V.Ts. Veterinariya Kubani, 2014, 1: 10-12 (in Russ.).

6. Neustroev M.P. Myt loshadei v Yakutii (etiologiya, epizootologiya, mery bor'by i profilaktika) [Equine strangles in Yakutia (etiology, epizootology, control measures, and prevention)]. Novosibirsk, 2000 (in Russ.).

7. Bizhanov A.B., Sansyzbai A.R., Namet A.M., Baidarov A.Kh. Zharshy, 1997, 6: 13-18 (in Russ.).

8. Boyle A.G., Timoney J.F., Newton J.R., Hines M.T., Waller A.S., Buchanan B.R. Streptococcus equi infections in horses: guidelines for treatment, control, and prevention of strangles-revised consensus statement. Journal of Veterinary Internal Medicine, 2018, 32(2): 633-647 (doi: 10.1111/jvim.15043).

9. Dzhetigenov E.A., Bektashev A.B., Aitbaev A.A. Vestnik Kyrgyzskogo natsional'nogo agrarnogo universiteta im. K.I. Skryabina, 2016, 2(37): 190-194 (in Russ.).

10. Khartford O.M.(IE), Foster T.D. (IE), Yakobs A.A.K. (NL). Shtamm i kul'tura shtamma Streptococcus equi TW 928 dlya vaktsinatsii loshadei. A.c. $R U 2194752$ C2 MPK ${ }^{7}$ A $61 \mathrm{~K} \mathrm{39/09.} \mathrm{Za-}$ yavl. 24.01.97. Opubl. 30.12.02 [Strain and culture of Streptococcus equi TW 928 for vaccination of horses. A.c. RU 2194752 C2 $\mathrm{MPK}^{7}$ A 61 K 39/09. Publ. 24.01.97. Bull. 30.12.02] (in Russ.).

11. Nearmat-Allah A.N.F., Damaty H.M. Strangles in Arabian horses in Egypt: clinical, epidemiological, hematological, and biochemical aspects. Veterinary World, 2016, 9(8): 820-826 (doi: 10.14202/vetworld.2016.820-826).

12. Berezhnaya L. Veterinariya sel'skokhozyaistvennykh zhivotnykh, 2008, 8: 20-27 (in Russ.).

13. Kim J.W., Jung J.Y., Lee K., Lee H., Kim H.Y., Yoon S.S., So B.J., Choi E. A case of Streptococcus equi subspecies zooepidemicus infection in a thoroughbred horse. Journal of Comparative Pathology, 2018, 158: 137 (doi: 10.1016/j.jcpa.2017.10.133).

14. Libardoni F., Machado G., Gressler L.T., Kowalski A.P., Diehl G.H., dos Santos L.C., Corbellini L.G., de Vargas A.C. Prevalence of Streptococcus equi subsp. equi in horse and associated risk factors in the State of Rio Grande do Sul, Brazil. Research in Veterinary Science, 2016, 104: 53-57 (doi: 10.1016/j.rvsc.2015.11.009).

15. Webb K., Barker C., Harrison T., Heather Z., Steward K.F., Robinson C., Newton J.R., Waller A.S. Detection of Streptococcus equi using a triplex qPCR assay. Veterinary Journal, 2013, 195(3): 300-304 (doi: 10.1016/j.tvj1.2012.07.007).

16. Cordoni G., Williams A., Duram A., Florio D., Zanoni R.G., Ragione R.L. Rapid diagnosis of strangles (Streptococcus equi subspecies equi) using PCR. Research in Veterinary Science, 2015, 102: 162-166 (doi: 10.1016/j.rvsc.2015.08.008).

17. Boyle A.G., Stefanovski D., Rankin S.C. Comparison of nasofaryngeal and guttural pouch specimens to determine the optimal sampling site to detect Streptococcus equi subsp. equi carriers by DNA amplification. BMC Veterinary Research, 2017, 13: 75 (doi: 10.1186/s12917-017-0989-4).

18. Boyle A.G., Rankin S.C., Duffee L., Boston R.C., Wheeler-Aceto H. Streptococcus equi detection polimerase chain reaction assay for equine nasopharyngeal and guttural pouch wash samples. Journal of Veterinary Internal Medicine, 2016, 30(1): 276-281 (doi: 10.1111/jvim.13808).

19. Cvetojević D., Radanović O., Milićević V., Jezdimirović N., Kureljušić B. Polyarthritis in goatkids caused by streptococcus equi subspecies zooepidemicus. Acta Veterinaria-Beogra, 2017, 67(3): 432-440 (doi: 10.1515/acve-2017-0035).

20. Khoult D.G., Krig N., Smit P., Steili Dzh., Uill'yams S. Opredelitel' bakterii Berdzhi. Tom 2 [Bergey's keys to bacteria. Volume 2]. Moscow, 1997 (in Russ.).

21. Metodicheskie ukazaniya po laboratornoi diagnostike myta [Methodical instructions for laboratory diagnostics of strangles]. Moscow, 2007 (in Russ.).

22. Shevchenko A.A., Chernykh O.Yu., Shevchenko L.V., Dzhailidi G.A., Zerkalev D.Yu., Litvinova A.R., Dvadnenko O.V. Diagnostika stafilokokkozov $i$ streptokokkozov [Diagnosis of staphylococcosis and streptococcosis]. Krasnodar, 2013 (in Russ.). 
23. Ashmarin I.P., Vorob'ev A.A. Statisticheskie metody v mikrobiologicheskikh issledovaniyakh [Statistical methods in microbiological research]. Leningrad, 1962 (in Russ.).

24. Wilson K. Preparation of genomic DNA from bacteria. Current Protocols in Molecular Biology, 2001, 56(1): 241-245 (doi: 10.1002/0471142727.mb0204s56).

25. Zhirkov A.D., Tatarinova S.S., Tarabukina N.P., Neustroev M.P. Agrarnyi vestnik Urala, 2013, 7(113): 20-21 (in Russ.).

26. Neustroev M.P., Tarabukina N.P., Petrova S.G., El'byadova E.I. Trudy VIEV, 2018, 80(1): 268272 (doi: 10.18411/978-5-9906389-2018-243-247) (in Russ.).

27. Dauvillier J., Woort F., Erck-Westergren E. Fungi in respiratory samples of horses with inflammatory airway disease. Journal of Veterinary Internal Medicine, 2018, 33(2): 968-975 (doi: 10.1111/jvim.15397).

28. Pelkonen S., Lindahl S.B., Suomala P., Karhukorpi J., Vuorinen S., Koivula I., Väisänen T., Pentikäinen J., Autio T., Tuuminen T. Transmission of Streptococcus equi subspecies zooepidemicus infection from horses to humans. Emerging Infectious Diseases, 2013, 19(7): 1041-1048 (doi: 10.3201/eid1907.121365).

29. Laing G., Christley R., Stringer A., Aklilu N., Ashine T., Newton R., Radford A., Pinchbeck G. Respiratory disease and sero-epidemiology of respiratory pathogens in the working horses of Ethiopia. Equine Veterinary Journal, 2018, 50(6): 793-799 (doi: 10.1111/evj.12834).

30. Smith F.L., Watson J.L., Spier S.J., Kilcoyne I., Mapes S., Sonder C., Pusterla N. Frequency of shedding of respiratory pathogens in horses recently imported to the United States. Journal of Veterinary Internal Medicine, 2018, 32(4): 1436-1441 (doi: 10.1111/jvim.15145).

31. North S.E., Wakeley P.R., Mayo N., Mayers J., Sawyer J. Development of a real-time PCR to detect Streptococcus equi subspecies equi. Equine Veterinary Journal, 2013, 46(1) (doi: 10.1111/evj.12088). 